Halaman: 19-27

p-ISSN 2252-6900 I e-ISSN 2502-4531

\title{
UNNES
}

Catharsis: Journal of Arts Education

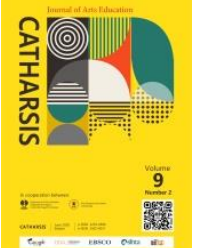

http://journal.unnes.ac.id/sju/index.php/chatarsis

\section{Sada Sabai Dance in Komering Culture of East OKU Regency}

\section{Ika Aditia Candra Buana ${ }^{\bowtie}$, Hartono Hartono, Triyanto Triyanto}

E-mail: Ikabuana.45@gmail.com

\author{
Universitas Negeri Semarang, Indonesia
}

Received 26 December 2019, Accepted 27 Februaryl 2020, Published 31 May 2020

\begin{abstract}
Sada Sabai dance as one of South Sumatra's traditional art works, especially in East Ogan Komering Ulu Regency is very closely related to Komering culture. Sada Sabai dance is one of the characteristics of the Komering culture that dwells in the South Sumatra region, created based on the spirit of the Komering community when holding a traditional wedding ceremony. Sada Sabai dance is one form of art that is used by many Komering people who are presented during the traditional wedding ceremony. The problem raised in this study aims to analyze the characteristics of the Sada Sabai dance that developed in the Komering culture. The method used is a qualitative method with a case study research design. Data collection techniques include observation, interview and document study. The results showed that Sada Sabai dance was a symbol of the harmony between the bride and groom family, so that in the past Sada Sabai dance was only danced by married families. This phenomenon was clearly seen when the groom's family and the bride danced on the stage how the two of them looked very close to each other. Then, the movement in Sada Sabai dance emphasized improvisation and exploration as its main approach and the main characteristic lied in the middle fingers of the dancers.
\end{abstract}

Keywords: Sada Sabai Dance, Characteristics, Komering Culture

DOI : https://doi.org/10.15294/catharsis.v9i1.38475 


\section{INTRODUCTION}

Art as an element of culture has an important meaning in the effort to develop the culture of the nation. Therefore, the arts need to be observed, preserved, and socialized continuously. One of the reasons for the extinction of traditional art is that the relay sticks for the preservation of traditional art are stopped for the next young generation. Likewise, because there is no next generation that cares, the art will slowly age and eventually die without a trace. Traditional art as a form of Nusantara's cultural wealth must indeed be fair, meaning to pay attention according to needs (Endraswara, 2012: 65). Of course, if traditional art already has a special place to take part, then it is possible for the next generation to advance and develop. However, if traditional art which has constraints in terms of development and preservation, either there is no place for art or the concern of local youth is low, it needs extra work and serious attention especially from the government if it does not expect the traditional art to lose its supporters.

Likewise, the art in South Sumatra Province, especially in the area of East Ogan Komering Ulu Regency or often abbreviated as East $O K U$ which has a diversity of arts and culture that until now still maintained, although some areas of the East $O K U$ community are not entirely familiar with the traditional traditional arts this region well. This is due to the fact that East $O K U$ Regency is part of the South Sumatra Province. Not all of the people support the original East $O K U$ culture, namely the Komering culture, but several ethnic groups reside in the East $O K U$ region, which was initiated by the transmigration program. The tribe in question is Sundanese, Javanese, Balinese and those who are indeed of all ethnic groups carry their respective cultural traditions.

Therefore, it is only natural that there are a number of cultural arts passed down from generation to generation of the original Komering tribe who reside in East $O K U$ experience stagnation in the process of introduction to the general public, especially the people who reside in East $O K U$. One of the traditional arts that is currently a concern of the East $O K U$ Government in the effort to preserve is the Sada Sabai dance.

Wulandari (2018) explained that the Sada Sabai dance is a traditional dance that developed in the East $O K U$ region in the South Sumatra region. Especially the Komering Tribe, where the Sada Sabai dance has developed since a long time ago and eventually became a hereditary tradition. The function of the Sada Sabai dance is a dance performed to welcome the in-laws to the wedding custom and danced directly by the family and the in-law pohak themselves. Sada Sabai dance is precisely danced by both families, namely the family of the bridegroom and the bride.

Sada Sabai dance is generally a dance between the two parties in-laws (family) movements that are danced have spontaneous movements (oral) or no variety of movements and this dance can only be danced by families who are married or married. Because basically this dance is presented only as a symbol of closeness between the bride and groom family. That is, the Sada Sabai dance functioned as an intermediary symbol of the sacredness of the two big families. As Wadiyo (2006) explains that music or art are generally expressions of human culture that are always present as personal expressions and / or expressions of social groups based on the culture they refer to, from which they can be used or utilized by individuals and / or social groups in society for humans as a means of temporary social interaction. Like for example one of the Islamic music arts that is named hadroh music. Kurniawan A \& Firmansyah. D (2020) writes that the hadroh ethnic music group is a musical work of art intended both for the artists themselves, connoisseurs of art, and also the surrounding community for the purpose of entertainment and to add positive activities in the Islamic environment.

In such a position art which is the product of cultural products of the community can be used as a characteristic of a certain group or ethnicity, as told in the writings of Wadiyo and Kurniawan. A, in the paragraph above. Therefore, in this paper we will write down the characteristics of the Sada Sabai dance that 
developed in Komering culture in East $O K U$ Regency as one of the cultural products of the Komering people which has been passed down for generations to date.

\section{METHOD}

The method used in this research is qualitative method. That is, the resulting data is descriptive data in the form of words (can be spoken for religious, social, cultural, philosophical research), notes relating to meaning, values and understanding. The model of this method in observing research data is not limited and is isolated with variables, populations, samples and hypotheses. In addition, qualitative methods always have a holistic nature, namely interpretation of data in relation to various aspects that might exist (Kaelan 2012: 5).

The approach used is a cultural approach, with a case study research design. The research location was in Martapura District, East Ogan Komering Ulu Regency (East OKU). Data collection techniques used include observation, interview and document study. The observation method used in this study is ordinary observation. That is, researchers do not need to be involved in emotional relations with the actors who are the target of his research (Rohidi 2011: 184). In addition, the interview technique used in this study was an in-depth interview. While the data validity technique uses data triangulation techniques. The data analysis technique used is an interactive model analysis flow starting from data collection, data reduction, data presentation and data verification.

\section{RESULTS AND DISCUSSION}

The Emergence of Sada Sabai Dance in the Komering Culture

Talking about an ethnic or the Komering tribe, then it will not be separated from the discussion of its unique customs and culture, one of which is the art of dance that they named the Sada Sabai dance. Sada Sabai dance is one of the traditional dances that was created based on the cultural phenomenon of the Komering community at that time. The naming of one of the traditional arts of the Komering tribe, namely Sada Sabai dance is taken from the basic premise of the creation of the dance art. According to Leo Rachmadi (interview, 13 October 2019), sada means the family of the bride, while sabai means the family of the bridegroom. Starting from this understanding, then the dance which was then performed during the Komering traditional wedding ceremony procession was named the Sada Sabai dance. The Komering tribe which currently lives in the Eastern $O K U$ region are indeed very thick with cultural customs that are usually used as traditional ceremonies. However, this reality is only nostalgic, this is due to the political arrangement of the territorial division made in accordance with the rules of the Government of Indonesia.

Dedi Firmansyah (2015) one of the reasons for the decline in the existence of Komering's cultural arts began in 1979, when a central government regulation was adopted that replaced the clan government system and was later replaced by the name District. The impact of the change in the system of government that initially became a clan does not only affect the boundaries of each clan area. But it also has a bearing on the arts and culture which initially became the full responsibility of Pesirah as the supreme leader of the clan, which is indeed one of its tasks to safeguard cultural assets inherited by the Komering tribe ancestors.

Then, Rachman (in Adhuri. D. S, 2002) explained politically, the term clan was a system of community regulation in South Sumatra introduced by the Palembang sultanate in the 18th century. This system was then adopted by the colonial governments of the Netherlands, Japan and Indonesia before the enactment of Law No.7 of 1979. It seems that, technically, the formation of clans by the sultanate of Palembang was done by binding several (from three to tens) of arrogant people who lived in adjacent areas into organizational unity under the leadership of an official called pasirah. As a result, different from its socio-cultural roots, in this context the clans have turned into social organizations on the 
basis of territorial ties. One area that adheres to the clan government system is the Komering tribe which currently lives on the edge of the Komering river.

Specifically Kurniawan (2017) writes that the Komering tribe is a term for naming the children of tribes who used to live and spread along the river flow, now the river is known as the Komering river, so that the sea slowly the term develops and eventually it is also used as the name of a tribe who resides on the banks of the river. Even though the clan government system has now changed to Subdistrict, the Komering community especially in East $O K U$ still considers that the clan government system cannot be eliminated.

Naming the origin of the community in East $O K U$ often remains related to the origin of the clan. Even the current government system in East $O K U$ also forms the traditional leaders of the Komering tribe who are intentionally assigned to safeguard the local wisdom values of Komering culture, both from language, culture, and traditional arts such as the Sada Sabai dance which is commonly used as a tribal customary need. The Komering.

Technically, the Sada Sabai dance is very closely related to the traditional activities of Komering, such as when the traditional wedding ceremonies of Komering Sada Sabai dance are always present and become a unity when the wedding ceremony takes place. Azis (2017) explains marriage is a physical and spiritual bond between a man and woman to live together and form a family. Or more simply marriage is an inner and outer bond between a man and a woman as husband and wife with the aim of forming a happy and eternal family (household) based on the Godhead of the Almighty. According to some informants, it is true that the Komering tribe is an ethnic culture that is quite old and strongly adheres to the rules of Islamic law. It is very relevant if the custom of the Komering community to hold a wedding ceremony at the place of residence, this is nothing but an expression of gratitude and pengikralan that the united hearts were celebrated at a wedding.
Based on this spirit, the Sada Sabai dance was created and presented at the Komering wedding. Rusnawi (interview, 10 October 2019) added that Sada Sabai dance was one of the ways used by the traditional elders of Komering in the past to familiarize themselves between the bride and groom's family. When the families danced on the stage, the clarity of both parties was very clear. So, the Sada Sabai dance can be said to symbolize the harmony between the bride and groom family. This phenomenon is in line with the wayang wong show written by Arisyanto, Prasena, et al (2017) where the wayang wong with the title "Encounter the Sky Kissing the Earth" is about the cultural differences that exist in Indonesia and how it should respect the cultural differences of each region as a unifying tool of the nation. This illustrates how the public uses art as a medium of expression of taste, an expression of the soul that can be observed from the two arts that researchers present. As Setyorini. I. Y (2012) asserts that art acts as a medium of communication, so that a form of art that will be born, grow and develop based on the situation and condition of the community where the art shows its existence, and is able to survive in changing times while growing certain souls (in other terms called art elasticity).

\section{Characteristics of Sada Sabai Dance in Komering Culture}

When in dance performance motion is one of the most important elements. Where motion in dance is an activity of curvation or swinging of the body that is intended. In other words, the motion in dance is a beautiful motion, whereas the motion meant by a beautiful motion is a motion that has received a touch of art. As Sumandio Hadi (2003: 15) explains that motion in dance is the processing of a beauty of motion that has undergone stilative (processing) and distortive (reshuffle process) processes that still have a specific purpose or are often referred to as motion meaning. Then Mega, Yustika \& Mohammad Hasan Bisri (2017) added that the movements in dance can be divided into two, namely meaningful motion and pure motion. Both types of motion are manifestations and 
experiences of dance artists which are processed into motion so that they become one composition or choreography. Furthermore, from the two movements Sumandio Hadi (2003: 11) explains that pure motion is a motion that does not have specific purposes and aims to get beauty only, while meaningful motion is a motion that has certain purposes and has been stylized.

For this reason, the grouping or compilation of movements that have been chosen by dance artists is then arranged in a very calculating manner, with the intention that the dance that is later presented has the right meaning in accordance with the chosen theme. As Jazuli, M (2001) explained that the form and content of dance is a form of dance. The form itself is a form that is interpreted as a result of various dance elements that include a unity of variation, repetition, transition, series, comparison and climax. More modestly Aprilina (2014) adds that in a member of the human body consisting of head, body, hands and feet and fingers and toes that can produce a rhythmic and dynamic motion that has been arranged and assembled and integrated into an arrangement dance moves intact with elements of a dance. In other words, such an arrangement is indeed often used in composing a movement in a dance.

However, if it relates to the Sada Sabai dance that is owned by the Komering community, the motion used in this dance is not the same as the arrangement of motion that is commonly used in dance in general. In other words, when presenting the Sada Sabai dance there is only one main movement that is used, namely the waving motion and the subsequent movements of the dancer are required to improvise. Pebrianti. S. I (2013) explains that the principal sequence of motion is a long unit of motion, which contains a representation of a particular meaning. Waving motion is the only motion used in the Sabai sadai dance, waving motion is played with the body position slightly tilted forward, and the dancer's ankles are slightly lowered down. As stated by Mr. Rusnawi (interview, 2019) explained that when dancing Sada Sabai dance does not use too much motion, there is only one motion that is waving both hands. Then, the motion is repeated and usually there are additional movements, but it depends on each dancer. The following researchers include an excerpt of his interview with Mr. Rusnawi (interview, 2019); "Initially, the Sada Sabai dance was created as a dance of keakrap between the bride and groom's family, in my opinion, it is not surprising that there is no such thing as just playing around, because it does not burden the narikenyo. But even though only waving both hands, according to my great-grandfather's narrative, the two dancers' hands were raised somewhat upward, well, it was as if they were giving thanks because their two children had already married. "

The quote above is a narrative of the main research source source, namely Mr. Rusnawi, who until now is an artist and cultural leader of Komering who consistently maintains cultural customs in the Martapura sub-district environment. If it is understood carefully, it is indeed the case if the motion in the Sada Sabai dance is monotonous and does not change, only raising both hands and swinging it. According to the researcher's hemad and based on the narrative of the source of the dance movement, sadai sabai is classified as meaningful motion, because the waving motion has been stylized and then arranged into the sabai sadai dance, and then prioritizes the spontaneity of the dancer or often known as improvisation. As stated by Yustika, Mega \& Mohammad Hasan Bisri (2017) who added that meaningful motion, where motion has a special meaning. This can be reflected in one of the Sada Sabai dance movements where the dancer's legs cross, which means the meeting of the two parties in-law to open themselves because of the arrival of a new family. The words of greeting greet each other, while the scarf ties the string of unity or strengthens the bond of marriage.

However, there are some important points that researchers can convey in order to understand the motion of the Sada Sabai dance which has its main characteristics. The main characteristic that researchers can observe in this Sada Sabai dance movement lies in the curve of the wrist and the flick of the fingers. Such visual form is not too obvious, but this is a uniqueness that is possessed in this traditional Komering 
traditional dance. Where possible motion with a flick of the hand as in the Sada Sabai dance cannot be found in traditional dances in other areas. For example in the bridal fence dance which is one of the cultural assumptions of the Government of South Sumatra, Kartikasari (2019) Pagar Pengantin dance is a group dance consisting of companion dancers and core dancers, which is the main characteristic in this dance located in intin dancers. Where the main dancer when presenting the fence dance is the bride bride. That is, in such a position, a traditional dance that developed in every culture must have characteristics that can then explain where the dance originated. As Azzahra, Fatimah (2015) Each region has different cultural characteristics and one form of cultural characteristics of each region is manifested by its unique cultural dance. Then the characteristics of a traditional art in every culture as intended by researchers can also be understood through writing Sudono, et al (2013) write that this lion dance is the culture of the Chinese community. The nuances that emerge when people see this show, have already brought our minds to culture that originated in China. This feeling is reinforced by all kinds of identity symbols inherent in Liong and the Lion Dance as a whole. This phenomenon, gives a description to researchers that the characteristics of a traditional art that develops in a group of people seems to be able to provide a new understanding, so that it is embedded in human memory and in the future the data stored in memory will automatically appear and give understanding to the individual or which is often referred to as perception. Larasati. W (2017) explains perception can be interpreted as a view or assessment of someone's object, the assessment of each person for the same object can be different depending on the skills and personality of each.

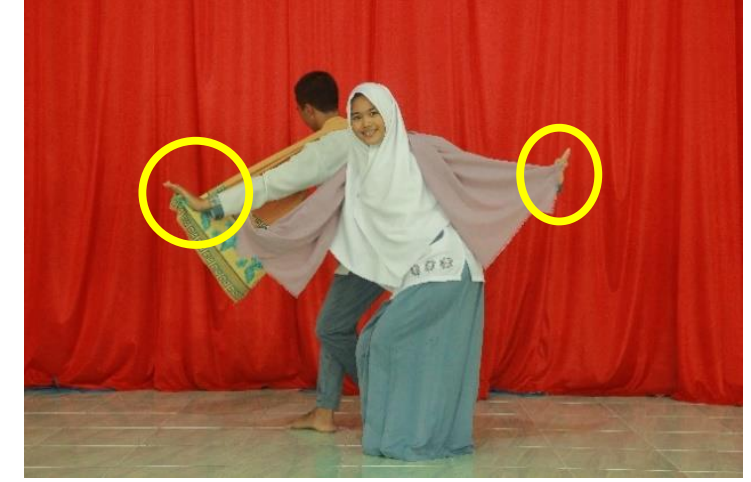

Figure 1. Curvation of hand movement in Sada Sabai dance.

It is clearly seen the position of the female dancer's wrist when moving her wrist (yellow circle), and then the fingers are being moved up and down, this is what is understood by the Komering people in East $O K U$ known as the flick of the fingers and all of them are the main features of Sada Sabai dance which developed in Komering culture. Visualization of motion in a dance can indeed be found in dances in other regions, for example motion in the Bedhaya Suryamirat dance, Puri. R. P. et al. (2015) wrote that aspects of the Bedhaya Suryasumirat dance movement have the same general characteristics as the Bedhaya dance in general, which is performed by nine female dancers.

The difference in the motion of the Bedhaya Suryasumirat dance to the other bedhaya dance movements lies in the merging of the motives of the movement, namely the merger between the Surakarta style dance movements and the Yogyakarta style dance movements. That is, the movements contained in a dance always have the characteristics of each, not fixated on a certain number and swing. Because indeed when traditional dance is created based on local knowledge which at the time gave birth to the birth of this traditional art, such as Sada Sabai dance and Suryasumirat bedhaya dance created by choreographers based on different spirits and knowledge. If in a dance movement that has a systematic sequence of movements is none other than what was stated Anjasuari et al (2017) explains that the systematic ordering is intended so that the choreographer or presenter 
understands the dynamics of the message to be conveyed in an art performance.

Next, the researchers included a photo of the Sada Sabai dance performance in Martapura District.

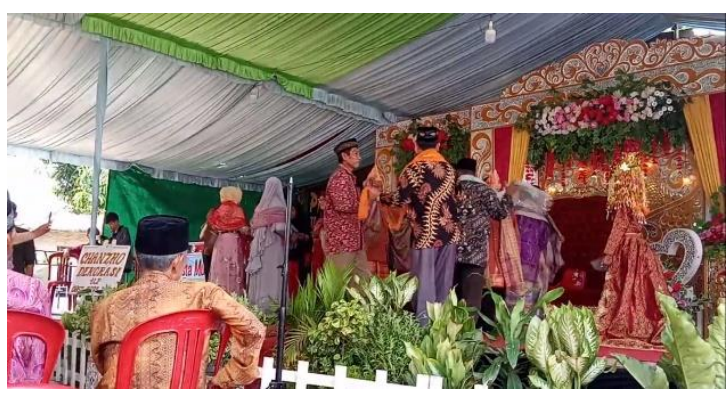

Figure 2. Sada Sabai dance show in the wedding ceremony of Komering society (Documentation: IKA, 2019)

As the researcher said at the beginning, that the naming of this traditional dance is the Sada Sabai dance based on the basic theme of the creation of this dance, namely the dance of keakrapan, if in Komering sada the party means the bride, and sabai means the party of the groom . That is, in a position like this the sabai sadai dance is interpreted as a symbol of the union of the two extended families of the bride and groom. As can be seen clearly in Figure 1 and according to Ibuk Darsini (interview, 2019) that there are two groups of dancers, namely men and women, the movements used are relatively slightly different. The motion of the male dancer's hand position is slightly widened and raised slightly parallel to the head, then the foot position takes an upright stance, but the right foot comes forward and opens slightly wide (the position of the horses). Another thing with the position of the female dancer's hand movements that open the hand is not too high, estimated position in front of her hips.

The difference between male and female dancers does not fully apply patent. That is, such a position can be changed at any time because there are times when dance actors or actors who do not understand the rules related to the rules of the dance Sada Sabai dance, because as researchers say that the motion in the dance Sada Sabai prioritizes improvisation and exploration into the main approach. When in a dance, Jazuli. M (2012) explains that the explorative method referred to in a dance movement is a way of learning dance that is exploratory to find a movement (motive) and dance form as a whole. That is, the curvature of the exploration motion incorporated in the Sada Sabai dance presentation in the Komering culture is an attempt to fill empty spaces that eventually unite every motive of the Sada Sabai dance movement intact.

\section{CONCLUSION}

Based on the results and discussion of "Sada Sabai dance in the Komering culture of East OKU Regency", Sada Sabai dance is one of the traditional arts of the Komering tribe which has a very important role in the needs of traditional ceremonies, namely wedding ceremonies. Where Sada Sabai dance is a symbol of harmony between the bride and groom family. This understanding is certainly passed down from generation to generation. The Sada Sabai dance is one of the methods used by the elders of Komering at the time as a medium for self-acclaiming between the bride and groom's family. When the families danced on the stage, the clarity of both parties was very clear. While the movements in Sada Sabai dance prioritize improvisation and exploration to be the main approach and the main characteristic lies in the middle fingers of the dancers. Then, the movements of male dancers and female dancers are slightly different. The motion of the male dancer's hand position is slightly widened and raised slightly parallel to the head, then the foot position takes an upright stance, but the right foot comes forward and opens slightly wide (the position of the horses). Another thing with the position of the female dancer's hand movements that open the hand is not too high, estimated position in front of her hips.

\section{REFERENCES}

Anjasuari, Ni Wayan Trisna dkk. 2017. Pertunjukan Tari Barong Sebagai Atraksi Wisata Di Desa Pakraman Kedewatan 
Kecamatan Ubud Kabupaten Gianyar. Dalam Jurnal Penelitian Agama Hindu. Vol 1. No 1 (hal 123-128). Institut Hindu Dharma Negeri: Denpasar

Aprilina, Finta Ayu Dwi. 2014. Rekonstruksi Tari Kuntulan Sebagai Salah Satu Identitas Kesenian Kabupaten Tegal. Dalam Jurnal Seni Tari. Vol 3. No 1 (hal 18). Jurusan Sendratasik, Fakultas Bahasa dan Seni: Universitas Negeri Semarang

Arisyanto. P, Agus C., Hartono. 2017. Wayang Kulit Wong Lakon Menjunjung Langit Mencium Bumi: Kajian Teks Pertunjukan. Dalam Catharsis: Journal of Arts Education Vol 7. No 1, (hal 74-81). Prodi Pendidikan Seni, Program Pascasarjana, Universitas Negeri Semarang

Aziz. Safrudin. 2017. Tradisi Pernikahan Adat Jawa Keraton Membentuk Keluarga. Dalam Ibda: Jurnal Kebudayaan Islam. Vol 15. No 1, (hal 22-41). Institut Agama Islam Negeri (IAIN) Purwokerto

Azzahrah, Fatimah. 2015. Revitalisasi Tari Sigeh Penguten Melalui Pendidikan Seni Budaya di SMP Negeri 1 Tanjung Raya Kabupaten Mesuji. Catharsis: Journal of Arts Education, 6(1), 38-48.

Darsini. (46). Seniman Budayawan Kabupaten OKU Timur. Provinsi Sumatera Selatan.

Endaraswara, Suwardi. 2012. Metodelogi Penelitian Kebudayaan. Yogyakarta: Gajah Mada University Press.

Hadi, Sumandiyo.2003. Aspek-aspek Dasar Koreografi Kelompok. Yogyakarta: elKAPHI.

Jazuli. M. 2012. Model Pembelajaran Tari Pendidikan Pada Siswa Sd/Mi Semarang. Dalam Harmonia: journal_of_arts research_and_education. Vol 10. No 2, (hal 1-18). Staf Pengajar Sendratasik, FBS, UNNES.

Kaelan, H. 2012. Metode Penelitian Kualitatif Interdisipliner Bidang Sosial, Budaya, Filsafat, Seni, Agama dan Humaniora. Yogyakarta: Paradigma

Kartika. A., Tjetjep. R. R., Triyanto. 2019. Ekspresi simbolik dan nilai etika budaya gerak tari pagar pengantin. Dalam
Catharsis: Journal of Arts Education Vol 8. No 4, (hal 419-428). Prodi Pendidikan Seni, Program Pascasarjana, Universitas Negeri Semarang

Kurniawan. A \& Firmansyah. D. 2020. Seni Musik Etnik Hadrah Nur Muhammad Di Kecamatan Jayaloka Kabupaten Musirawas Kajian Bentuk Sajian Dan Struktur Musik. Dalam Jurnal Geter: Jurnal Seni Drama Tari dan Musik. Vol 3. No 1, (hal 52-63). Fakultas Bahasa Dan Seni. Universitas Negri Surabaya.

Kurniawan, Arif. 2017. Penanaman Identitas Kedaerahan dalam Pendidikan Seni. Dalam Dedy Irawan (ed). Paradigma Pendidikan Seni. Yogyakarta: Thafa Media. Kurniawan. Arif. 2017. Kulintang: Struktur Musik Dan Nilai Yang Tertanam Dalam Proses Belajar Pada Masyarakat Komering Di Kabupaten OKU Timur. Tesis. Universitas Negeri Semarang.

Larasaty, W. 2013. Persepsi Masyarakat Terhadap Pertunjukan Organ Tunggal Malam Hari Dalam Acara Pernikahan Di

Tebo. E-Jurnal Sendratasik FBS Universitas Negeri Padang, 2(1), 81-90. Retrieved from ejournal.unp.ac.id , Beranda > Vol 2, No 1 (2013) > Larasaty.

Mega, Yustika \& Mohammad Hasan Bisri. 2017. Bentuk Penyajian Tari Bedana Di Sanggar Siakh Budaya Desa Terbaya Kecamatan Kotaagung Kabupaten Tanggamus Lampung. Dalam Jurnal Seni Tari. JST Vol 6. No 1 (hal 1-10). Jurusan Pendidikan Seni Drama Tari dan Musik, Fakultas Bahasa dan Seni: Universitas Negeri Semarang

Pebrianti, Sestri Indah. 2013. Makna Simbolik Tari Bedhaya Tunggal Jiwa. Dalam Jurnal HARMONIA. Vol 13. No. 2. (Hal 120131). Program Studi Kajian Seni Petunjukan Pascasarjana, Universitas Gajah Mada, Jogjakarta

Putri. R. P. Wahyu. L, Sri Iswidayati. 2015. Relevansi Gerak Tari Bedaya Suryasumirat Sebagai Ekspresi Simbolik Wanita Jawa. Dalam Catharsis: Journal of Education. Vol 4. No 1, (1-7). Prodi 
Pendidikan Seni, Program Pascasarjana, Universitas Negeri Semarang

Rohidi, Tjetjep, Rohendi. 2011. Metodologi Pendidikan Seni. Semarang : Cipta Prima Nusantara.

Rusnawi (62) Seniman Musik Kulintang dan pemerhati budaya Komering di OKU Timur. Provinsi Sumatera Selatan.

Setyorini, I. Y. 2012. Norma-Norma Masyarakat. Jurnal Pendidikan Kewarganegaraan Universitas Negeri Malang, 1(1), 1-17.

Sudono, Suhartono, G. L. L. S. 2013. Pertunjukan Liong dan Barongsai di
Yogyakarta: Redefinisi Identitas Tionghoa. Panggung, 23(2), 227-240..

Wadiyo. 2006. Seni Sebagai Sarana Interaksi Sosial. Dalam Jurnal Humaniora Pengetahuan dan Pemikiran Seni. Vol VII. No 2: Universitas Negeri Semarang.

Wulandari. Mia. 2018. Tari Sada Sabai Di Ogan Komering Ulu Timur Sumatera Selatan Dan Upaya Pengembangannya. Dalam EJournal Seni Tari. Program Study Pendidikan Seni Tari Fakultas Bahasa Dan Seni. Universitas Negeri Yogyakarta. 